\title{
Comparison of walking measures in patients with HTLV-1 Associated Myelopathy
}

\author{
Adine Adonis ${ }^{1 *}$, Graham P Taylor ${ }^{1,2}$ \\ From 17th International Conference on Human Retroviruses: HTLV and Related Viruses \\ Trois Ilets, Martinique. 18-21 June 2015
}

Walking, a fundamental, complex, multifunctional task, is demanding of multiple body systems, interactively affecting walking capacity. Due to their restricted walking ability, activity and participation levels in patients with HTLV-1-Associated Myelopathy (pwHAM) are compromised. Primarily, the applicability of walking endurance using the 6 minute walk $(6 \mathrm{MW})$ and gait speed using the timed $10 \mathrm{~m}$ walk (10mTW), in pwHAM, were explored. Distance covered, change over one year and the influence of pain were documented. Retrospectively, case notes were abstracted for gait $(6 \mathrm{MW}$; $10 \mathrm{mTW}$ ) and pain, for all pwHAM, walking a minimum of $10 \mathrm{~m}$, at least 11 months apart. 26 pwHAM, (8-; 18-) met the assessment criteria. Mean age 58.5 years and disease duration was 10.46 years \pm 6.02 years. Observed distance walked $(55 \mathrm{~m}$ at $\mathrm{T} 1$ and $71 \mathrm{~m}$ at $\mathrm{T} 2)$ was shorter $(\mathrm{p}<0.01)$ than expected for age, gender and height $(610 \mathrm{~m})$. Using a patient's $10 \mathrm{mTW}$ velocity to predict the $6 \mathrm{MW}$ distance overestimates the actual distance walked in 6 minutes $(\mathrm{p}=.00 ; \mathrm{p}=.00)$. Initially the $10 \mathrm{mTW}$ velocity, accounted for $35 \%$ of the variance of the 6MWdistance $(\mathrm{F}=.59 ; \mathrm{p}=.00)$, improving to $63 \%(\mathrm{~F}=$ $.00 ; \mathrm{p}=.00)$. Patients' $10 \mathrm{mTW}$ velocities versus healthy age matched controls differed at baseline $(\mathrm{p}=0.00)$ and follow-up $(p=0.00)$. Using a walking aid strongly correlated with the $10 \mathrm{mTW}$ at both time points ( $\mathrm{rs}=.78$ $\mathrm{p}=.00 ; \mathrm{rs}=.85 \mathrm{p}=.00$ ). Change in pain was not significant over time. $23 \%$ (baseline)- $42 \%$ (followup) of our pwHAM, completed the $6 \mathrm{MW}$. Acting as their own controls, the distance covered for the $6 \mathrm{MW}$ is much shorter compared to predicted values. The $10 \mathrm{mTW}$ velocity underestimated the degree of disability, usefully predicted functional domains and highlighted functional

\footnotetext{
* Correspondence: adine.adonis@imperial.nhs.uk

${ }^{1}$ National Centre for Human Retrovirology, St Mary's Hospital, Imperial

College Healthcare NHS Trust, London, UK

Full list of author information is available at the end of the article
}

decline. The $6 \mathrm{MW}$, independent of the $10 \mathrm{mTW}$ velocity, provides a functional measure of endurance. Walking capacity in pwHAM can be measured using the $10 \mathrm{mTW}$ for gait speed and the $6 \mathrm{MW}$ for endurance. These appear to represent different indicators of walking efficacy in pwHAM.

\section{Authors' details}

${ }^{1}$ National Centre for Human Retrovirology, St Mary's Hospital, Imperial College Healthcare NHS Trust, London, UK. 'Section of Retrovirology and GU Medicine, Department of Medicine, Imperial College, London, UK.

Published: 28 August 2015

\section{doi:10.1186/1742-4690-12-S1-017}

Cite this article as: Adonis and Taylor: Comparison of walking measures in patients with HTLV-1 Associated Myelopathy. Retrovirology 2015 12(Suppl 1):017.

\section{Submit your next manuscript to BioMed Central and take full advantage of: \\ - Convenient online submission \\ - Thorough peer review \\ - No space constraints or color figure charges \\ - Immediate publication on acceptance \\ - Inclusion in PubMed, CAS, Scopus and Google Scholar \\ - Research which is freely available for redistribution

